\begin{tabular}{l|l|l} 
Jurnal Eksplorasi Akuntansi (JEA) & $\begin{array}{l}\text { e-ISSN : 2656-3649 (Online) } \\
\text { hol. 3, No 4, November 2021, Hal 811- } 821\end{array}$
\end{tabular}

\title{
Manajemen Laba: Pengaruh Keahlian Keuangan Komite Audit dan Gender
}

\author{
Shofia Salsabila ${ }^{*}$, Salma Taqwa ${ }^{2}$ \\ ${ }^{1,2}$ Fakultas Ekonomi, Universitas Negeri Padang \\ *Korespondensi: shofiashalsabila19@gmail.com
}

\begin{abstract}
The purpose of this study is to see how the influence of the audit committee's financial expertise and gender on earnings management. The type of associative research is used in this study. Manufacturing companies listed on the Indonesia Stock Exchange in 2017-2019 were selected in this study. The sample in this study was selected through the purposive sampling method and obtain 153 observations. Earnings management as dependent variable is measured using discretionary accrual by modified jones model (1991). the measurement of independent variable audit committee financial expertise used the percentage of audit committee with financial expertise, while gender is measured using dummy variable. The result of this study found that audit committee's financial expertise and gender havo no significant effect on earnings management.
\end{abstract}

Keywords: Audit Committee's Financial Expertise; Earnings Management; Gender.

How to cite (APA $6^{\text {th }}$ style)

Shofia, S. \& Taqwa, S. (2021). Manajemen Laba: Pengaruh Keahlian Keuangan Komite Audit dan Gender. Jurnal Eksplorasi Akuntansi (JEA), 3 (4), 811-821.

\section{PENDAHULUAN}

Laporan keuangan perusahaan akan menjadi fokus utama para pemangku kepentingan dalam menilai kinerja suatu entitas atau perusahaan. Hal ini disebabkan karena laporan keuangan dapat memberikan gambaran tentang bagaimana kondisi internal perusahaan. Laporan keuangan juga merupakan suatu bentuk pertanggung jawaban manajemen sebagai hasil akhir dari suatu proses akuntansi. Salah satu komponen utama dalam laporan keuangan dan menjadi acuan para pemangku kepentingan dalam menilai kinerja perusahaan adalah informasi mengenai laba perusahaan (Agyei-Mensah \& Yeboah, 2019).

Pentingnya informasi laba bagi pihak eksternal perusahaan mendorong perusahaan untuk memungkinkan pihak manajemen untuk melakukan kecurangan. Manajemen akan melakukan berbagai cara agar laporan keuangan perusahaan dapat terlihat baik. Tindakan yang dilakukan manajemen ini dikenal dengan istilah manajemen laba. Tindakan manajemen laba dalam suatu perusahaan tidak dapat dihindari, karena praktik manajemen laba merupakan efek dari penggunaan basis akrual dalam pelaporan keuangan. Penggunaan basis akrual dalam proses akuntansi sejatinya digunakan karena dianggap dapat menggambarkan bagaimana kondisi perusahaan yang sebenarnya. Akan tetapi, disisi lain penggunaan dasar akrual memberikan peluang kepada pihak manajemen dalam menentukan metode akuntansi 
selama tidak menyalahi Standar Akuntansi Keuangan yang telah ditetapkan (Pangestika \& Murdianingrum, 2014).

Faktor lain yang memungkinkan perusahaan melakukan tindakan manajemen laba adalah kesenjangan informasi (information asymmetry) yang dimliki dan diterima oleh perusahaan (agent) dan pemangku kepentingan (principal). Dalam praktik manajemen laba pihak manajemen selaku agent menguasai lebih banyak informasi tentang perusahaan sedangkan pihak eksternal tidak memiliki akses yang cukup untuk mengumpulkan informasi tentang perusahaan (Scott, 2015).

Scott (2015) menyatakan bahwa manajemen laba merupakan pilihan manajer dalam menetukan pilihan kebijakan akuntansi atau suatu tindakan nyata yang dilakukan manajemen untuk mempengaruhi laba dalam mencapai tujuan tertentu. Khrisnan \& Pearson (2008) menjelaskan bahwa praktik manajemen laba terkait dengan pilihan metode akuntansi yang menyediakan pelaporan laba yang menguntungkan pihak manajemen tetapi merugikan pihak lain. Tanggungjawab manajer bukan hanya terhadap pimpinan perusahaan dalam mencapai tujuan perusahaan. Manajer juga bertanggungjawab penuh kepada pihak-pihak pemangku kepentingan yang dalam menyediakan laporan keuangan yang berkualitas tinggi.

Kasus manajemen laba yang pernah terjadi di Indonesia ialah kasus perusahaan penerbangan PT. Garuda Indonesia Tbk. PT. Garuda Indonesia Tbk diduga melakukan praktik manajemen laba. Sejak tahun 2015 PT. Garuda Indonesia diberitakan sudah mengontrol laporan keuangan agar terlihat sehat dengan memundurkan semua pembayaran hutang. Pemunduran itu dimaksudkan membuat laporan keuangan menjadi bagus sehingga bagi para pengguna informasi dari PT. Garuda akan melihat bahwa PT. Garuda selalu memiliki laporan keuangan bagus dan sehat (Energy world, 2016).

Para pemangku kepentingan membutuhkan alat atau jembatan agar dapat mengurangi kecenderungan manajemen terlibat dalam tindakan manajemen laba (Krishnan \& Pearson, 2008). Oleh karena itu, dibutuhkan suatu corporate governance mechanism yang berfungsi sebagai pengendalian internal perusahaan yang bertujuan untuk mengawasi tindakan manajemen laba dalam perusahaan.

Keberadaan komite audit dalam perusahaan diharapkan dapat menjadi penghubung antara perusahaan dan pemangku kepentingan. Komite audit berperan dalam melakukan monitoring mechanism dalam membatasi tindakan oportunistik manajer yang merupakan cerminan dari teori keagenan yang menyatakan bahwa perusahaan membutuhkan suatu mekanisme pengawasan terhadap tindakan oportunistik manajer (Sultanaa et al, 2015).

Menurut Dwiharyadi (2017) komite audit ialah komite yang dibentuk dan bertanggungjawab kepada Dewan Komisaris dalam melaksanakan fungsi dan tugas dewan komisaris. Peran penting komite audit dalam perusahaan adalah untuk mengawasi proses pelaporan keuangan perusahaan. Badolato (2014) berpendapat bahwa untuk menghindari terjadinya skandal akuntansi, banyak negara membutuhkan anggota komite audit yang memiliki keahlian dibidang keuangan. Di Indonesia, sebagaimana tertera dalam Peraturan Otoritas Jasa Keuangan No. 55/POJK.04/2015 menyebutkan komite audit memiliki paling sedikit 3 anggota dan salah satu diantaranya harus memiliki keahlian dalam bidang keuangan maupun akuntansi.

Zalata et al (2018) bependapat bahwa gender komite audit berperan dalam membatasi terjadinya manajemen laba. Hassan et al (2015) menyatakan bahwa gender merupakan suatu status yang dibentuk melalui sarana sosial, budaya dan psikologis yang didasarkan pada sifatsifat pribadi. Sedangkan Mutmainah dalam Razak (2020) mendeskripsikan gender sebagai suatu konsep yang menjabarkan tentang perbedaan antara wanita dan pria jika diamati dari aspek non biologisnya, seperti aspek budaya, sosial dan perilaku.

Penelitian mengenai pengaruh keahlian keuangan komite audit terhadap manajemen laba memang sudah banyak dilakukan sebelumnya, akan tetapi penelitian mengenai pengaruh 
gender khususnya gender keahlian keuangan masih sangat jarang diteliti. Oleh karena itu, peneliti tertarik untuk meneliti tentang keahlian dan gender anggota komite audit dalam praktik manajemen laba.

Penelitian ini bertujuan untuk mengetahui bagaimana pengaruh keahlian keuangan dan gender anggota komite audit dalam membatasi praktik manajemen laba dalam perusahaan. Perbedaan penelitian dari penelitian sebelumnya terdapat pada alat ukur dan data yang digunakan. Penelitian ini menggunakan dummy score sebagai proxy gender dan data yang digunakan adalah perusahaan manufaktur yang terdaftar di Bursa Efek Indonesia tahun 2017-2019.

\section{REVIU LITERATUR DAN HIPOTESIS}

Jensen and Meckling (1976) menyatakan bahwa agensi teori merupakan sebuah hubungan kontrak dimana salah satu pihak (principal) melibatkan orang lain (agent) untuk melakukan beberapa layanan atas nama mereka termasuk pendelegasian beberapa kuasa dalam pengambilan keputusan kepada agent. Scott (2015) menyatakan bahwa teori agensi merupakan cabang dari game theory yang mempelajari tentang desain kontrak untuk mendorong agent bertindak atas nama principal ketika kepentingan agent bertentangan dengan principal. Perbedaan tujuan antara manajemen dan principal akan mempengaruhi keputusan yang akan diambil oleh manajemen (Zirman, 2017).

Keberadaan komite audit dalam perusahaan dinilai dapat memberikan manfaat bagi perusahaan. Hal ini disebabkan karena peran komite audit dalam melakukan pengawasan yang merupakan cerminan dari prinsip teori keagenan yang menyatakan bahwa perusahaan membutuhkan suatu mekanisme pengawasan terhadap tindakan oportunistik manajer (Sultana et al, 2015). Ikatan Komite Audit Indonesia (IKAI) menyatakan bahwa keberadaan komite audit diharapkan dapat meningkatkan kualitas pengawasan internal perusahaan dan mengoptimalkan mekanisme checks and balances, sehingga memberikan perlindungan terbaik bagi pemegang saham dan pemangku kepentingan lainnya

Scott (2015) mendefinisikan manajemen laba sebagai pilihan manajer dalam menentukan kebijakan akuntansi, atau tindakan nyata yang mempengaruhi laba untuk mencapai beberapa tujuan tertentu. Gavious et al (2012) menyatakan bahwa umumnya manajemen laba dapat diartikan sebagai praktik penggunaa metode akuntansi diskresioner untuk mencapai tingkat laba yang diinginkan untuk dilaporkan.

Berdasarkan Peraturan Otoritas Jasa Keuangan Nomor 55/POJK.04/2015, komite audit merupakan komite yang dibentuk dan bertanggungjawab kepada dewan komisaris dalam menjalankan tugas dan fungsinya. Komite audit merupakan komite yang dibentuk oleh dewan komisaris untuk mengaudit operasional perusahaan (Istiantoro, 2018). Dalam pedoman kerja komite audit yang dimuat dalam Peraturan Otoritas Jasa Keuangan Nomor 55/POJK.04/2015, menekankan bahwa setiap komite audit harus memiliki setidaknya satu anggota dengan latar belakang atau keahlian keuangan. Ahli keuangan ialah orang yang memiliki latar belakang pendidikan akuntansi dan keuangan atau pernah menduduki jabatan penting di bidang akuntansi atau keuangan (Wardhani dan Joseph, 2010).

Gender merupakan salah satu faktor yang mempengaruhi sikap kerja. Gender mengacu pada seperangkat karakteristik yang membedakan antara pria dan wanita, yang mencerminkan ciri biologis atau mencerminkan identitas gender seseorang (Sari \& Supadmi, 2014). Mutmainah (dalam Razak, 2020) mendeskripsikan gender sebagai suatu konsep yang menjelaskan tentang adanya perbedaan antara wanita dan pria jika diamati dari aspek nonbiologisnya, seperti aspek budaya, sosial dan perilaku. 


\section{Keahlian Keuangan Komite Audit dan Manajemen Laba}

Komite audit merupakan komite yang dibentuk dan bertanggung jawab kepada Dewan Komisaris dalam melaksanakan tugas dan fungsinya. Dhaliwal et al (2010) menyatakan bahwa komite audit yang paling efektif dapat tercapai ketika perusahaan menggunakan kombinasi direktur akuntansi dan keuangan independen yang terlatih. Secara khusus, mereka menetapkan seorang direktur sebagai ahli keuangan di komite audit apabila mereka adalah direktur independen dan memiliki pelatihan di bidang akuntansi dan keuangan, telah menjadi direktur eksekutif di departemen akuntansi dan keuangan perusahaan lain dan pernah menjadi anggota komite audit perusahaan lain (Mensah, 2019).

Teori agensi menunjukkan bahwa peningkatan pengawasan dewan melalui komite audit dapat mengurangi biaya agensi. Sultana (2015), menyatakan bahwa kehadiran anggota dengan keahlian keuangan dapat meningkatkan kemampuan komite audit untuk memastikan pekerjaan auditor eksternal dilakukan secara kompeten, dan memahami penilaian audit. Oleh karena itu, komite audit harus memiliki pengalaman yang diperlukan dalam menyusun dan mengaudit laporan keuangan dan akuntansi untuk akrual, estimasi, dan cadangan (Dhaliwal, 2010). Oleh karena itu, keberadaan ahli keuangan diantara anggota komite audit dapat memecahkan persoalan keagenan termasuk manajemen laba dalam perusahaan yang muncul akibat adanya perbedaan kepentingan antara principal dan agent. Selanjutnya hipotesis dari penelitian ini adalah sebagai berikut:

H1: Keahlian keuangan komite audit berpengaruh negatif terhadap manajemen laba.

\section{Gender Komite Audit dan Manajemen Laba}

Selain keahlian yang dimiliki komite audit, penelitian sebelumnya menunjukkan bahwa karakter pribadi seperti perbedaan gender dapat mempengaruhi perilaku etis. Jika keputusan manajemen laba merupakan keputusan etis, maka manajemen laba dapat dipengaruhi oleh gender pembuat keputusan. Akan tetapi, meskipun perbedaan gender dapat mempengaruhi keputusan etis individu, tidak dapat dipastikan sejauh mana perbedaan gender akan mempengaruhi keputusan kelompok yang dibuat oleh komite audit.

Sun (2011) juga berpendapat bahwa manajemen laba dapat dibatasi ketika mayoritas komite audit percaya bahwa manajemen laba terjadi dan komite harus bertindak untuk melawannya. Jika wanita lebih etis daripada pria, maka anggota komite audit wanita lebih meyakini bahwa manajemen laba tidak etis dan akan berusaha untuk mempengaruhi komite sehingga mayoritas ketua komite audit akan memilih untuk bertindak melawan manajemen laba. Dorongan dan kemampuan seorang komite audit wanita dalam membatasi manajemen laba tidak hanya bergantung pada keyakinan tetapi juga pada berbagai faktor individu dan kelompok. Selanjutnya, hipotesis dari penelitian ini adalah sebagai berikut:

H2: Gender anggota komite audit wanita yang memiliki keahlian keuangan lebih cenderung mengurangi manajemen laba dibandingkan anggota komite audit pria yamg memiliki keahlian keuangan.

\section{METODE PENELITIAN Jenis Penelitian}

Penelitian asosiatif merupakan jenis penelitian yang digunakan. Penelitian asosiatif termasuk dalam metode penelitian kuantitatif, yaitu penelitian yang digunakan jika data yang disajikan berbentuk angka dan dianalisis secara statistik untuk menarik kesimpulan (Sugiyono, 2013). Penelitian ini menguji pengaruh variabel bebas (independen) terhadap varibel terikat (dependen). 


\section{Populasi dan Sampel}

Populasi yang akan diteliti dalam penelitian ini merupakan seluruh perusahaan manufaktur yang terdaftar di Bursa Efek Indonesia (BEI) pada periode pengamatan tahun 2017-2019. Dalam penelitian ini, sampel dipilih melalui teknik purposive sampling dengan kriterianya adalah (1) perusahaan manufaktur yang terdaftar dan mempublikasikan laporan keuangan yang telah diaudit di BEI selama tahun 2017-2019, (2) periode pelaporan keuangannya berakhir pada tanggal 31 Desember dan dalam satuan mata uang rupiah, serta (3) menyediakan data yang lengkap sesuai kebutuhan penelitian. Jumlah sampel terkumpul berdasarkan kriteria yang ditentukan adalah sebanyak 51 perusahaan.

\section{Jenis, Sumber Data dan Teknik Pengumpulan Data}

Data dokumenter merupakan jenis data yang dipakai dalam penelitian ini dan sumber datanya adalah data sekunder. Dalam mendapatkan data yang dibutuhkan, peneliti memakai teknik dokumentasi untuk mendapatkan laporan keuangan dan laporan tahunan perusahaan pada tahun 2017-2019. Data tersebut diperoleh dengan mengakses situs www.idx.co.id dan situs-situs terkait.

\section{Variabel Dependen}

Manajemen laba merupakan variabel dependen dalam penelitian ini, yaitu tindakan campur tangan pihak manajemen dalam proses pelaporan keuangan eksternal dengan tujuan menguntungkan diri sendiri, diproksikan dengan discretionary accrual yang dihitung menggunakan Model Jones yang dimodifikasi (Dechow et al,. 1995) dengan tahapan sebagai berikut:

a) Menghitung total accrual (TAC), dengan rumus sebagai berikut:

$$
\text { TAC }=\text { NIit }- \text { CFOit }
$$

Keterangan:

TAC $=$ Total accrual

NIit $\quad=$ Laba bersih

CFOit $\quad=$ Arus kas dari aktivitas operasi

Selanjutnya, total accrual (TA) diestimasi dengan Ordinary Least Square sebagai berikut:

$$
\text { TAC }_{\text {it }} / \mathbf{A i t}_{\text {it } 1}=\alpha_{1}\left(1 / A_{i t-1}\right)+\beta_{1}\left(\Delta R E V_{t} / A_{i t-1}\right)+\beta_{2}\left(P_{P E t} / A_{i t-1}\right)+e
$$

Keterangan:

TACit = total akrual perusahaan I pada periode $\mathrm{t}$

Ait-1 $=$ Total aset perusahaan i pada periode $\mathrm{t}-1$

$\triangle \mathrm{REV}_{\mathrm{t}}=$ Perubahan pendapatan perusahaan $\mathrm{i}$ dari tahun $\mathrm{t}-1 \mathrm{ke}$

$\mathrm{PPE}_{\mathrm{t}}=$ Property, plant, and equipment perusahaan tahun $\mathrm{t}$

b) Menghitung nondiscretionary accruals (NDA). NDA ditentukan dengan formula sebagai berikut:

$$
\mathrm{NDA}_{i t}=\alpha_{1}\left(1 / A_{i t-1}\right)+\beta_{1}\left(\Delta R E R_{t} / A_{i t-1}-\Delta R E C_{t} / A_{i t-1}\right)+\beta_{2}
$$

c) Terakhir, discretionary accruals (DA) sebagai ukuran manajemen laba ditentukan dengan formula berikut :

$$
\text { DAC } i t=\text { TAC }_{\text {it }} / \mathbf{A}_{i t-1}-\text { NDAit }
$$


Keterangan:

$\mathrm{DA}_{\mathrm{it}} \quad=$ Discretionary Accruals perusahaan i dalam periode tahun $\mathrm{t}$

TAit $=$ Total acrual perusahaan $\mathrm{i}$ dalam periode tahun $\mathrm{t}$

$\mathrm{A}$ it-1 = Total assets perusahaan i dalam periode tahun $\mathrm{t}-1$

$\mathrm{NDA}_{\text {it }}=$ Nondiscretionary Accruals perusahaan i dalam periode tahun $\mathrm{t}$

\section{Variabel Independen}

a. Keahlian keuangan komite audit adalah orang yang memiliki latar belakang pendidikan akuntansi dan keuangan, dan bertanggung jawab kepada dewan komisaris untuk membantu pelaksanaan tugas dan fungsi dewan komisaris, diukur melalui perbandingan antara jumlah komite audit yang memiliki keahlian keuangan terhadap jumlah keseluruhan anggota komite audit.

$$
K K_{-} K A=\frac{\text { jumlah anggota komite audit yang memiliki keahlian kewangan }}{\text { jumlah seluruh aggota komite audit }} \times 100 \%
$$

b. Gender merupakan suatu konsep yang menjelaskan tentang adanya perbedaan antara wanita dan pria jika dipandang dari aspek nonbiologisnya, variabel ini diukur melalui skor dummy. Skor 1 diberikan jika perusahaan memiliki anggota komite audit wanita dengan keahlian keuangan dan skor 0 diberikan jika perusahaan yang tidak memiliki anggota komite audit wanita dengan keahlian keuangan.

\section{Teknik Analisis Data}

\section{Analisis Deskriptif}

Teknik deskriptif dipergunakan dalam hal menginterpretasikan atau menjabarkan nilai rata-rata, nilai maksimum dan minimum serta nilai standar deviasi dari masing-masing variabel penelitian yaitu variabel independen (keuangan komite audit dan gender) dan variabel dependen (manajemen laba).

\section{Uji Asumsi Klasik}

Uji asumsi klasik dipergunakan dalam menguji kelayakan dari penggunaan analisis regresi untuk pengolahan data pada suatu penelitian.

a. Uji Normalitas

Uji normalitas dipergunakan dalam menguji distribusi sebuah data apakah mendekati distribusi normal atau tidak. Pengambilan keputusan normalnya suatu data merujuk pada uji Komogolov Smirov dengan nilai sig. lebih besar dari 0,05 maka dapat berarti bahwa data terdistribusi normal.

b. Uji Multikolinieritas

Uji multikolinearitas dipergunakan dalam hal menguji model regresi apakah terdapat korelasi antar variabel bebasnya. Tidak terjadi kolerasi diantara variabel bebas merupakan model regresi yang baik. Penggunaan kolerasi bivariat digunakan dalam mendeteksi multikolinearitas antar variabel bebas dengan standar toleransi 0,80 .

c. Uji Autokolerasi

Untuk melihat dalam sebuah model regresi linear terdapat korelasi dibutuhkan uji autokorelasi. Uji Durbin Watson (DW Test) dapat dipakai dalam penentuan uji autokorelasi. Model regresi disebut terbebas dari autokorelasi jika nilai DW terletak diantara nilai $d u$ dan 4-du $(d u<D W<4-d u)$.

d. Uji Heterokedastisitas

Model regresi dilhat sudah baik apabila terjadi homoskedastisitas. untuk melihat ada atau tidaknya ditunjukkan dari uji Homokedastisitas, dasar pengambilan 
keputusannya yaitu jika signifikansinya lebih besar dari 0,05 maka tidak terjadi heteroskedastisitas.

\section{Analisis Regresi Linier Berganda}

Penelitian ini menggunakan metode statistika yaitu Analisis regresi. Adapun analisis regresi yang dipakai adalah analisis linier ganda (multiple regression analysis), dipakai untuk melihat/ menentukan kontribusi (koefisien korelasi) dari variabel $\mathrm{X}$ terhadap variabel $\mathrm{Y}$. Adapun persamaannya, adapun persamaannya, yaitu:

$$
\mathbf{D A}=\alpha+\beta_{1} \mathbf{K K} \_\mathbf{K A}+\boldsymbol{\beta}_{2} \mathbf{G K A}+\varepsilon
$$

Keterangan:

DA = discretionary accruals sebagai proxy pada manajemen laba

$\alpha \quad=$ konstanta

KK KA $=$ Keahlian Keuangan Komite Audit

GKA $=$ Gender Komite Audit

$\varepsilon \quad=$ Disturbance error

\section{Uji model}

a) Uji Koefisien Determinasi (Adjusted $\mathrm{R}^{2}$ )

Uji ini bertujuan untuk menguji goodness-fit dari model regresi dimana untuk mengukur seberapa jauh kemampuan model dalam menerangkan variasi variabel dependen maka dapat dilihat dari nilai adjusted $R^{2}$.

b) Uji F

Uji ini dipergunakan dalam menguji apakah model yang digunakan signifikan atau tidak. Jika $F_{\text {hitung }}$ yang lebih besar daripada $F_{\text {tabel, }}$, dapat dipastikan variabel independen secara bersama-sama berpengaruh terhadap variabel dependen, dengan tingkat kepercayaan untuk pengujian hipotesis adalah $95 \%$ atau $(\alpha)=0,05$.

c) Uji t-Test

Uji ini menggambarkan seberapa jauh pengaruh satu variabel dengan variabel independen lainnya terhadap variabel dependen. Uji t dapat juga dilakukan dengan melihat signifikansi t masing-masing variabel pada output hasil regresi dengan level signifikan $0,05(\alpha=5 \%)$.

\section{HASIL DAN PEMBAHASAN}

\section{Statistik Deskriptif}

Data penelitian menunjukkan bahwa variabel manajemen laba sebagai variabel dependen dalam penelitian ini memiliki nilai rata-rata $-0,03081315$ dengan standar deviasi sebesar 0,13508321. Nilai maksimum manajemen laba sebesar 0,671945959 dan nilai minimum manajemen laba sebesar -1,25577243. Variabel keahlian keuangan komite audit yang diberi tanda X1 memiliki nilai rata-rata sebesar 0,659041394 dengan standar deviasi 0,243587248 . Nilai maksimum untuk keahlian keuangan komite audit sebesar 1,00 dan nilai minimum sebesar 0,333333. Nilai maksimum untuk gender sebesar 1 dan nilai minimum sebesar 0 . 


\section{Uji Asumsi Klasik}

\section{Uji Normalitas}

Berdasarkan tabel diatas, dapat dilihat bahwa probability lebih kecil dari 0,05 yaitu 0,000 . Hal ini menandakan bahwa data penelitian ini belum terdistribusi normal. Namun, pada penelitian dengan jumlah data yang besar (>30), asumsi normalitas menjadi tidak terlalu penting.

\section{Uji Heterokedastisitas}

Pada uji glejser, model regresi dinilai tidak mengalami heterokedastisitas apabila probabilitas signifikansi pada variabel independen $>0,05$ dan akan mengalami heterokedastisitas apabila probabilitas signifikansi pada variabel independen $<0,05$. Berdasarkan tabel diatas, dapat diketahui setiap variabel pada penelitian memiliki nilai signifikansi pada variabel independen $>0,05$. Sehingga dapat disimpulkan data penelitian tidak mengalami heterokedastisitas.

\section{Uji Multikolinearitas}

Dari data penelitian terlihat bahwa nilai VIF masing-masing variabel terlihat memiliki nilai VIF $<10$ dan nilai tolerance $>0,1$ sehingga bisa dikatakan bahwa tidak ada gejala multikolinearitas.

\section{Uji Autokorelasi}

Data penelitian menunjukkan nilai Durbin Watson adalah 2,046. Nilai DW kemudian akan dibandingkan dengan nilai pada tabel Durbin Watson (DW). Jumlah sampel pada penelitian ini sebanyak $153(\mathrm{n}=153)$ sampel dan variabel independennya adalah $4(\mathrm{k}=4)$. Berdasarkan data pada tabel DW, didapatkan nilai dL sebesar 1,6824 dan dU sebesar 1,7896. berdasarkan data diatas, $\mathrm{dU}<\mathrm{dW}<4$-dU $(1,7896<2,037<2,2104)$ maka dapat disimpulkan bahwa tidak terjadi auto korelasi antar variabel independen pada penelitian ini, sehingga model regresi layak digunakan.

Analisis Regresi Berganda

$$
Y=-0.75+0.87 X 1-0.37 X 2+\varepsilon
$$

Dimana:

$\mathrm{Y}=$ Manajemen laba

$\alpha=$ Konstanta

$\beta_{1,2}=$ Koefisien regresi dari variabel independen

$\mathrm{X}_{1}=$ Keahlian keuangan komite audit

$\mathrm{X}_{2}=$ Gender

\section{Uji Model}

\section{Koefisien determinasi (Adjusted $\mathbf{R}^{\mathbf{2}}$ )}

Nilai adjusted $\mathrm{R}^{2}$ yang diperoleh sebesar 3,6\%. Hasil tersebut menunjukkan bahwa kontribusi variabel independen terhadap variabel dependen pada model yang digunakan dalam penelitian adalah sebesar 3,6\% dan sebesar 96,4\% ditentukan oleh variabel lain yang tidak digunakan dalam penelitian ini.

\section{Uji F (Simultan)}

Hasil penelitian menunjukkan bahwa $F_{\text {hitung }}$ untuk pengaruh X1 sampai X4 secara simultan terhadap manajemen laba senilai 2,776 dan nilai $F_{\text {tabel }}$ sebesar3,06. Hasil ini menunjukkan bahwa X1 dan X2 tidak berpengaruh signifikan secara simultan terhadap manajemen laba karena $\mathrm{F}_{\text {hitung }}$ lebih kecil dibanding $\mathrm{F}_{\text {tabel }}, 2,776<3,06$. 


\section{Uji t (Parsial)}

a. Hipotesis pertama menyatakan bahwa keahlian keuangan komite audit berpengaruh negatif terhadap manajemen laba. Berdasarkan tabel diatas, diketahui t sebesar 1,935 dan nilai koefisien regresi sebesar 0,087 dengan nilai signifikansi 0,055 . Hasil ini menunjukkan bahwa X1 tidak berpengaruh terhadap manajemen laba karena nilai signifikansi lebih besar dari $\alpha$, yaitu 0,055 $>0,05$. Berdasarkan hasil uji t dapat disimpulkan bahwa hipotesis pertama yang menyatakan keahlian keuangan berpengaruh negatif terhadap manajemen laba, ditolak.

b. Hipotesis kedua menyatakan bahwa gender berpengaruh negatif terhadap manajemen laba. Berdasarkan tabel diatas, diketahui nilai t sebesar -1,611 dan nilai koefisien regresi sebesar -0,037 dengan nilai signifikansi 0,109. Hasil ini menunjukkan bahwa gender tidak berpengaruh terhadap manajemen laba karena nilai signifikansi $>\alpha(0,05)$, yaitu $0,88>$ 0,05 . Berdasarkan hasil uji t dapat disimpulkan bahwa hipotesis kedua yang menyatakan gender berpengaruh negatif terhadap manajemen laba, ditolak.

\section{Pengaruh Keahlian Keuangan Komite Audit Terhadap Manajemen Laba}

Berdasarkan hasil analisis statistik dalam uji koefisien regresi parsial (uji t), ditemukan bahwa hipotesis ditolak. Sehingga disimpulkan bahwa keahlian keuangan komite audit tidak berpengaruh terhadap manajemen laba. penelitian ini tidak sejalan dengan penelitian Widasari et al (2017) yang menemukan bahwa keahlian komite audit berpengaruh negatif terhadap manjemen laba.

Peraturan yang telah ditetapkan oleh Otoritas Jasa Keuangan belum menjelaskan karakteristik apa sajakah yang harus dimiliki oleh seseorang agar dapat dinyatakan memiliki financial literacy. Sehingga, kurangnya penjelasan mengenai financial literacy yang dimiliki oleh anggota komite audit menyebabkan tiap perusahaan sampel memiliki pemahaman yang berbeda. Hal ini berpengaruh pada penunjukkan anggota komite audit yang memiliki financial literacy (Fitriasari dalam Pamudji \& Trihartati, 2010). Selain itu, komite audit hanya bertugas membantu dewan komisaris memiliki keterbasan dalam menjalankan fungsi, kewajiban dan hak mereka sehingga tanggung jawab komite audit terhadap dewan komisaris untuk membantu mereka dalam mengawasi Direksi dan manajemen serta memastikan penerapan prinsip-prinsip tata kelola perusahaan yang baik, menjadi terbatas (Sari, 2019).

Hasil penelitian ini sejalan dengan peneltian yang telah dilakukan Dwiharyadi (2017) yang menemukan tidak terdapat pengaruh antara keahlian keuangan komite audit terhadap manajemen laba.

\section{Pengaruh Gender Terhadap Manajemen Laba}

Berdasarkan hasil analisis statistik dalam uji koefisien regresi parsial (uji t), tidak ditemukan pengaruh antara bahwa hipoesis ditolak. Sehingga disimpulkan bahwa keahlian keuangan komite audit tidak berpengaruh terhadap manajemen laba. hasil penelitian ini tidak sejalan dengan hasil penelitian Sudarman \& Hidayat (2019) yang menemukan bahwa gender komite audit berpengaruh negatif terhadap manajemen laba.

Perbedaan peran antara pria dan wanita disebabkan karena adanya faktor sosial dan bukan faktor biologis.

Peran gender dapat berubah dalam kondisi, waktu, dan tempat yang berbeda sehingga peran pria dan wanita dapat dipertukarkan. Alasan lain yaitu karakteristik komite audit yang dapat mendeteksi dan menurunkan manajemen laba tidak didasari oleh gender (Afriliana\&Ariani, 2020). Sifat wanita yang cenderung lebih berhati-hati, lebih beretika dan risiko yang diduga dapat menurunkan manajemen laba tidak memiliki hubungan dengan tugas-tugas yang dilakukan komite audit dalam membatasi manajemen laba. Hasil penelitian 
ini sejalan dengan penelitian yang telah dilakukan Lestari (2015) yang menemukan tidak ada pengaruh antara gender komite audit terhadap manajemen laba.

\section{KESIMPULAN, KETERBATASAN DAN SARAN}

\section{Kesimpulan}

Berdasarkan hasil temuan dalam penelitian ini, dapat disimpulkan bahwa keahlian keuangan komite audit tidak berpengaruh terhadap manajemen laba atau menandakan bahwa keahlian keuangan yang dimiliki anggota komite audit tidak berpengaruh dalam mengindikasi dan membatasi praktik manajemen laba serta perbedaan gender anggota komite audit tidak berpengaruh dalam menurunkan praktik manajemen laba.

\section{Keterbatasan}

Meskipun peneliti telah berusaha merancang dan mengembangkan penelitian ini dengan sedemikian rupa, namun masih terdapat beberapa keterbatasan dalam penelitian yaitu :

a. Nilai Adjusted $\mathrm{R}^{2}$ masih menunjukkan pengaruh yang kecil yaitu 3,6\% sehingga besar kemungkian terdapat variabel-variabel lain yang berpengaruh terhadap manajemen laba diluar model regresi penelitian ini.

b. Sampel yang digunakan dalam penelitian ini hanya dilakukan pada perusahaan manufaktur.

c. Tahun pengamatan yang digunakan dalam pengambilan sampel hanya mencakup 3 tahun yaitu 2017 hingga 2019, hal ini dikarenakan keterbatasan informasi dan data yang tidak lengkap.

\section{Saran}

Beberapa saran yang dapat dikemukakan dalam penelitian ini yaitu:

a. Peneliti selanjutnya diharapkan dapat memperluas lingkup sampel yang digunakan karena penelitian ini hanya menggunakan perusahaan manufaktur sebagai objek penelitian.

b.Penelitian selanjutnya diharapkan dapat menggunakan variabel-variabel lain yang dianggap menjadi faktor penyebab terjadinya manajemen laba dan diharapkan dapat mempeluas kriteria keahlian keuangan komite audit.

c. Perusahaan diharapkan mampu mengendalikan faktor-faktor yang dapat memicu terjadinya manajemen laba, sehingga dapat mengurangi masalah keagenan yang disebabkan oleh adanya perbedaan kepentingan antara pihak-pihak internal perusahaan.

\section{DAFTAR PUSTAKA}

Afriliana, N., \& Ariani, N. E. (2020). Pengaruh Gender Chief Executive Officer(CEO), Financial Expertsise CEO, Gender Komite Audit, Financial Expertise Komite Audit Dan Ukuran Komite Audit Terhadap Audit Delay Pada Perusahaan Manufaktur yang Terdaftar di BEI Periode 2015-2017. Jurnal Ilmiah Mahasiswa Ekonomi Akuntansi, 5(1), 24-35.

Agyei-Mensah, B. K., \& Yeboah, M. (2019). Effective audit committee, audit quality and earnings management: evidence from the Ghana Stock Exchange. International Journal of Managerial and Financial Accounting, 11(2), 93-112.

Badolato, P. G., Donelson, D. C., \& Ege, M. (2014). Audit committee financial expertise and earnings management: The role of status. Journal of accounting and economics, 58(23), 208-230.

Dwiharyadi, A. (2017). Pengaruh keahlian akuntansi dan keuangan komite audit dan dewan komisaris terhadap manajemen laba. Jurnal Akuntansi dan Keuangan Indonesia, 14(1), 75-93. 
Gavious, I., Segev, E., \& Yosef, R. (2012). Female directors and earnings management in high-technology firms. Pacific Accounting Review.

Hassan, R., Marimuthu, M., \& Johl, S. K. (2015). Diversity, corporate governance and implication on firm financial performance. Global Business and Management Research, 7(2), 28.

Ikatan Komite Audit Indonesia (IKAI)

Istiantoro, I., Paminto, A., \& Ramadhani, H. (2018). Pengaruh Struktur Corporate Governance terhadap Integritas Laporan Keuangan Perusahaan pada Perusahaan LQ45 yang Terdaftar di BEI. AKUNTABEL, 14(2), 157-179.

Jensen, M. C., \& Meckling, W. H. (1976). Theory of the firm: Managerial behavior, agency costs and ownership structure. Journal of financial economics, 3(4), 305-360.

Krishnan, G. V., \& Parsons, L. M. (2008). Getting to the bottom line: An exploration of gender and earnings quality. Journal of Business Ethics, 78(1), 65-76.

Lakhal, F., Aguir, A., Lakhal, N., \& Malek, A. (2015). Do women on boards and in top management reduce earnings management? Evidence in France. Journal of Applied Business Research (JABR), 31(3), 1107-1118.

Lestari, T. K. (2015). Pengaruh Karakteristik Personal Komite Audit Terhadap Manajemen Laba Dalam Perusahaan Manufaktur Yang Terdaftar Di Bursa Efek Indonesia (Doctoral dissertation, STIE Indonesia Banking School).

Pamudji, S., \& Trihartati, A. (2010). Pengaruh Independensi dan Efektivitas Komite Audit Terhadap Manajemen Laba. Jurnal Dinamika Akuntansi, 2(1)

Pangestika, R., \& Murdianingrum, S. L. (2014). Pengaruh independensi dan efektivitas komite audit terhadap manajemen laba (Studi Empiris pada Perusahaan Manufaktur yang Terdaftar di Bursa Efek Indonesia Tahun 2010-2012). Jurnal Telaah dan Riset Akuntansi, 7(2), 131-141.

Peraturan Otoritas Jasa Keuangan Nomor 55/POJK.04/2015

Razak, B., \& Helmy, H. (2020). Pengaruh Dewan Direksi Wanita, Dewan Komisaris Wanita Dan Kualitas Pengungkapan Corporate Social Responsibility Terhadap Manajemen Laba. Jurnal Eksplorasi Akuntansi, 2(4), 3434-3451.

Redaksi. 2016. Kasus BUMN, Sejak Juni 2015 Keuangan PT Garuda Indonesia Sudah di Manipulasi. Diakses 25 Agustus 2021. https://energyworld.co.id/2016/03/12/kasusbumn-sejak-juni-2015-keuangan-pt-garuda-indonesia-sudah-dimanipulasi/

Rofika Zirman, Efektifitas Peran Komite Audit Terhadap Hubungan Financial Distress Dan Manajemen Laba,Universitas Jember : Symposium Nasional Akuntansi 20, 2017

Sari, A. L. (2019). Karakteristik Perusahaan, Tata Kelola Perusahaan dan Manajemen Laba. Jurnal Akuntansi Bisnis, 15(2), 229-245.

Scott, William R. 2015. Financial Accounting Theory, $7^{\text {th }}$ Edition. Toronto: Pearson Prentice Hall

Sudarman, W. A., \& Hidayat, W. (2019). Audit committee and earnings management: the role of gender. Jurnal Akuntansi, 23(3), 379-392.

Sultana, N., \& Mitchell Van der Zahn, J. L. (2015). Earnings conservatism and audit committee financial expertise. Accounting \& Finance, 55(1), 279-310.

Sun, J., Liu, G., \& Lan, G. (2011). Does female directorship on independent audit committees constrain earnings management?. Journal of Business Ethics, 99(3), 369-382.

Wardhani, R., \& Joseph, H. (2010). Karakteristik pribadi komite audit dan praktik manajemen laba. Simposium Nasional Akuntansi XIII, 1-26.

Zalata, A. M., Tauringana, V., \& Tingbani, I. (2018). Audit committee financial expertise, gender, and earnings management: Does gender of the financial expert matter?. International review of financial analysis, 55, 170-183. 